\title{
Development of Computer-Based Instruction Based Learning Models in Electricity Transmission Engineering Lessons SMK Negeri 1 Precut Sei Tuan
}

\author{
Muhammad Iqbal Daulay ${ }^{1}$, R. Mursid ${ }^{2}$, Baharuddin $^{3}$ \\ ${ }^{1}$ Postgraduate Program in Educational Technology,Universitas Negeri Medan, Indonesia \\ ${ }^{2,3}$ Universitas Negeri Medan, Indonesia \\ Muhammadiqbal_daulay@yahoo.co.id
}

\begin{abstract}
One of the formal education pathways that prepare its graduates to have excellence in the world of work is Vocational High Schools (SMK). Current problems in SMK are generally related to limited equipment, low practice costs, and a learning environment that is not suitable for the world of work. Education is carried out to achieve human resources with the ability to think which is formulated as "Higher Order Thinking Skills" (HOTS) which aims to form human resources with the ability to innovate and be able to solve problems. In developing CBI-based learning models, there are learning models that aim to provide a concrete learning experience through the creation of imitations of experiences that are closer to the actual atmosphere. Computer-based learning is strongly influenced by cognitive learning theory, a model of information processing that began to develop in the 60 s and 70 s.
\end{abstract}

Keywords

CBI-based learning model; information processing model; SMK

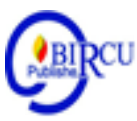

\section{Introduction}

One of the formal education pathways that prepare its graduates to have an edge in the world of work is a Vocational High School (SMK). Education is carried out to achieve human resources (HR) with the ability to think which is formulated as "Higher Order Thinking Skills" (HOTS) which aims to form HR with the ability to innovate and be able to solve problems. Based on Widiastuti (2019) the curriculum is one component to produce achieving learning. According to Imelda (2019) the ability to think critically consists of the dimensions of the process of analyzing and evaluating, the ability to think creatively consists of the dimensions of the creating process.. Several studies have revealed a relationship between the quality of vocational education and economic growth, highlighting the fact that human capital is the key to growth. Meanwhile, the current condition of employment in Indonesia is still marked by a high unemployment rate. Judging from the level of education by the table for the open unemployment rate (TPT) according to the Central Statistics Agency (BPS) in August 2019, the highest was still dominated by Vocational High Schools (SMK) among other education levels, namely 10.42\%. Hidayat (2020) states that High Order Thinking Skills which in Indonesian are known as high level thinking skills. High-level thinking skills students think patterns by relying on the ability to analyze, create, and evaluate all aspects and problems. 
Table 1. Open Unemployment According to the Highest Education Completed in 2018

\begin{tabular}{|c|l|l|l|}
\hline No. & The Highest Enthusiastic Education & \multicolumn{2}{|c|}{2018} \\
\hline 1 & No / Never attended school & Februari & Agustus \\
\hline 2 & No, / Have not graduated from elementary school & 446.812 & 31.774 \\
\hline 3 & Primary school & 967.630 & 896.962 \\
\hline 4 & Junior High School & 1.249 .761 & 1.131 .214 \\
\hline 5 & General High School & 1.650 .636 & 1.930 .320 \\
\hline 6 & Vocational High School & 1.424 .428 & 1.731 .743 \\
\hline 7 & Diploma/Academy & 300.845 & 220.932 \\
\hline 8 & University & 789.113 & 729.601 \\
\hline & Amount & $\mathbf{6 . 8 7 1 . 2 6 4}$ & $\mathbf{7 . 0 0 0 . 6 9 1}$ \\
\hline
\end{tabular}

Current problems in SMK are generally related to limited equipment, low practice costs, and a learning environment that is not suitable for the world of work. Schools have limitations in financing and providing a learning environment to increase national competitiveness, which is synonymous with improving the quality of human resources. In OECD (Organization for Economic Co-operation and Development) countries the development of vocational education has been implemented for a long time. This can be seen from the high enrollment rates in vocational secondary education for Austria, the Netherlands, Germany, and Turkey.

The World Economic Forum (WEF) states that Indonesia's competitiveness (Global Competitiveness Index, GCI) in 2014 is at 34th place. Meanwhile, in 2015 Indonesia's position has decreased to be in 37th rank with a value of 4,521, or if compared to 2014 decreased by three levels. This ranking is under Thailand (32), South Korea (26), Malaysia (18), and Singapore (2). If Indonesia does not prepare for the provision of intermediate to professional skilled workers, starting from improving access and quality of secondary education, certainly, Indonesia will only become a shelter for intermediate to professional skilled workers from member countries of the AEC (ASEAN Economic Community). Information and communication technology has developed along with globalization so that interaction and delivery of information will take place quickly. People from different countries can exchange information, science and technology. But on the other hand, this creates a digital-divide or a striking difference between those who are able and unable to access the use of ICT (Information and Communications Technology).

In line with the 2015-2019 RPJMN, the PSMK Directorate in the 2015-2019 strategic plan has a vision of the formation of character and vocational education ecosystems based on cooperation. The implementation of SMK services must be by the needs of the workforce to support the harmony of vocational education and strengthen the implementation of learning, so each SMK must have a permanent relationship with the industry for all stages of learning to start from planning, implementation, learning process, supervision and assessment. Also, the level of success of national development is closely related to the quality of human resources. 


\section{Review of Literatures}

In the CBI-based learning model, there are learning models that aim to provide a concrete learning experience through the creation of imitation forms of experience that are closer to the actual atmosphere and learning theories that aim to improve the quality of the learning process. The application of the computer-based learning model in the learning process in the subject of electric power transmission technique for vocational students in the development of a CBI-based learning model which includes:

\subsection{Learning Model}

Research on learning activities tries to find a learning model. The models found can be changed, retested and developed so that they can be applied in learning activities based on the learning patterns used. According to Rusman (2017: p.133), before determining the learning model, there are several things that the teacher must consider in selecting the learning model:

- Consideration of the learning objectives to be achieved.

- Considerations related to learning materials or materials.

- Consideration from the point of view of learners or students.

- Considerations of a non-technical nature

The pioneer of learning model research in America is Marc Belth (Rusman, p.131). Research on learning models has been carried out by several experts in America since the 1950s.

\subsection{Computer-Based Learning Models}

Computer-based learning models according to Rusman (2017: 290):

\section{a. Drills Model}

The drills model is a model in learning by training students with subject matter that has been given with continuous practice, it will be embedded and then become a habit. This model is derived from the Herbart learning model, namely the association model and response replication. The characteristics of drills in learning aim to provide a more concrete learning experience through the provision of question exercises aimed at testing student performance and abilities through the speed of completing practice questions given by computer-based learning programs, according to the opinion of Geisert and Futrell (1990: 85). ) which states that: "Drills or drills and practice programs, help learners refine or enhance. They normally complement classroom instruction by reinforcing skills already learned. In such programs, the usual job of the computer is repetitive and follows a district pattern. Explain that the routine is commonly quite simple:

- The learner is presented with a question or problem that corresponds to the target level of performance;

- The learner responds by typing in the answer;

- The computer evaluates the answer and provides feedback on its accuracy;

If the answer is correct the learner is presented with another question or problem, if the answer is not accurate the learner is allowed to try again. "

1. Curricular, namely implementing the curriculum as needed for each module and communicating it to students.

2. Learning, namely carrying out the learning process so that students actively learn independently through interactive programs that have been designed and defined. 
3. Diagnosis-guidance, which helps students who experience errors, mistakes, inaction, problems in computer-based learning based on the results of assessments, both formative and summative, so that students can guide themselves.

4. Administrative, namely carrying out recording, reporting, assessment, and other administrative techniques following the demands of the computer-based program; and

5. Personal, namely providing examples to students such as mastery of organizing material, learning methods, attitudes and behaviours that indirectly inspire independent learning motivation and high achievement motives.

\section{b. Simulation Model}

The simulation model is basically a learning strategy that aims to provide a more concrete learning experience through the creation of mock-ups of experiences that are closer to the actual situation and take place in an atmosphere without risk. In producing simulation models, it is necessary to pay attention to how to make simulations that can explain the material to be studied by students.

\section{c. Instructional Game Model}

The purpose of instructional games is to provide a learning experience that provides learning facilities to increase student abilities through educational games. Instructional games are a form of method in CBI-based learning.

\subsection{CBI-Based Learning Theory}

Learning (Instruction) shows the efforts of students to learn lesson material as a result of teacher treatment. This term is influenced by technological developments which are assumed to make it easier for students to learn everything through various media such as printed materials, television programs, pictures, audio, and multimedia to encourage a change in the role of teachers in managing the teaching and learning process, from the teacher as a source. learning to be a teacher as a facilitator in teaching and learning (Sanjaya, 2010: 102-103). As stated by Gagne (1992: 3) which states that "instruction is a set of events that affect learners in such a way that learning is facilitated".

In the CBI-based learning model, the use of computers is a centre of learning where students play a more active role in learning material using the main media of computers. According to Gagne, teaching or teaching is part of learning (instruction) where the role of the teacher is more emphasized on how to design or arrange various sources and facilities available to be used or utilized by students in learning something.

\subsection{Information Processing Theory}

Learning is closely related to cognitive, affective, and psychomotor development. Robert Gagne is the originator of the theory who views learning as the process of obtaining information, processing information, storing information, and recalling information controlled by the brain. A theory of learning from Gagne (1988) called Information Processing Learning Theory is a model of activity in the brain when processing information. Several models developed by Gagne (1984), Gagne and Berliner, and Lefrancois consist of three types of memory, namely: sensory memory, short-term memory/working memory, and long-term memory. New information that gets a student's attention will be categorized as a short-term store and entered into short-term memory/working memory as stated by Gagne and Berliner $(1988,285)$ as follows: "When 
we pay attention to a stimulus, the information represented by that stimulus goes into short-term memory or working memory".

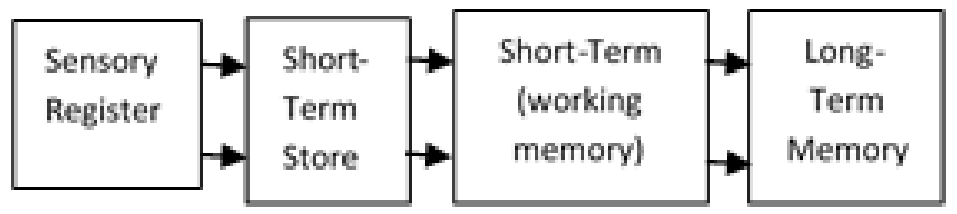

Figure 1. Information Processing Model

Under this model, data enters the memory system via a sensor register (Sensory Register), then is sent to short-term storage (Short-Term Store) for about 0.5 to 2 minutes for preliminary analysis. From this storage then sent to short-term memory or also known as working memory (Short-Term Memory). Here the analyzed data is stored for about 20 minutes. Then the data, after being transformed and coded, becomes part of the knowledge system stored in long-term memory (Long-Term Memory). In the process of storing shortterm storage and working memory, some data is lost from the system.

\subsection{Educational Media}

The word media comes from the Latin medius which literally means 'middle' or 'introduction'. The Association of Education and Communication Technology (AECT, 1977) in America defines the media as all forms and channels used to convey messages or information. One of the main functions of instructional media is as a teaching aid that contributes to the climate, conditions, and learning environment that teachers create (Abdul Gafur, 1979: 5).

To use the media as a tool, Dale's Cone of Experience (Dale, 1969) was introduced in the form of detailed elaboration of the concept of the three main levels of learning mode put forward by Bruner (1966: 10 - 11): direct experience (enactive), pictorial experience/picture (iconic), and abstract experience (symbolic).

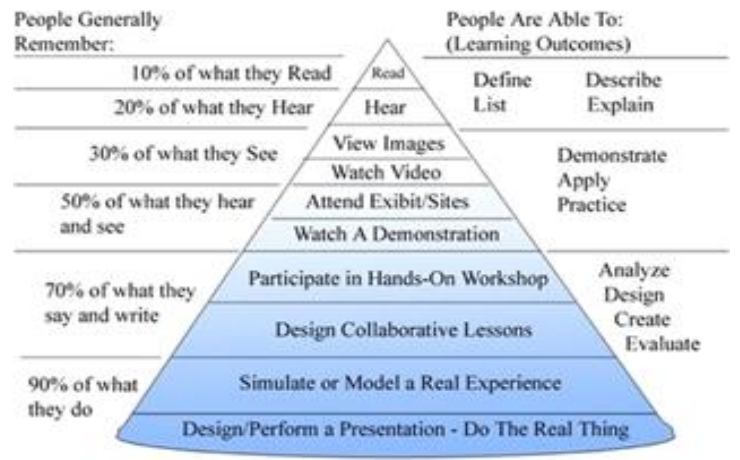

Figure 2. Dale's Cone Experience

\subsection{Development of CBI-Based Learning Theory}

In line with technological advances; Technological devices, particularly computers, have begun to be used in educational settings to develop visual materials such as animations and simulations, resulting in the development of CBI-based learning models. CBI-based learning can offer students opportunities to develop individual talents, knowledge, skills and self-fulfilment (KIE, 2008). Skinner's theory of operant conditioning had a tremendous influence on the development of early CBI-based learning (Shlechter, 1991). 
There are three basic assumptions about the behaviourist learning process: (1) behaviour rather than internal thought processes are focus, (2) the environment shapes behaviour, (3) the principles of closeness and reinforcement are central to explaining the learning process (Grippin \& Peters, 1983). The breakthrough from behaviourism occurred with the importation of insight learning ideas into Gestalt theory from Wertheimer, Koffka, and Kohler (Moore \& Fitz, 1993). In the laws of Gestalt study, there are laws of pragmas (principal) and subsidiary laws (additional) which are subject to the basic law.

Piaget and Bruner focused on cognition and instruction theory, which had an impact on learning theory. Piaget (1972) conceptualized the behaviour of the human organism starting with organizing sensory-motor reactions and becoming smarter as the coordination between reactions to objects became increasingly interrelated and complex. Bruner's interest (Knowles, 1984) is in organizing and sequencing knowledge and translating this into a theory of instruction. The basic theory of learning activities that he sees involves three almost simultaneous processes, namely: the acquisition of new information, the transformation or manipulation of knowledge to suit new tasks, and evaluation to see if the information is sufficient for the task. Gardner (1985, p. 6) defines cognitive science as a contemporary, empirically-based attempt to answer old epistemological questions, particularly those relating to the nature of knowledge, its components, sources, development and dissemination'. The three features cited by Gardner generally related to cognitive science as applicable to computer-based instruction are (1) cognitive science is explicitly multi-disciplinary, drawing primarily on the disciplines of psychology, linguistics, anthropology, philosophy, neuroscience, and artificial intelligence; (2) the main problem for this discipline is the cognitive representation, shape, structure, and manifestation at various levels; and (3) the belief that computers will prove central to the solution of cognitive science problems, both in researching to investigate various cognitive representations and in providing a viable model of the thought process itself (Bednar et al., 1995).

From a constructivist point of view, the teacher plays a more facilitative role, supporting learners in a self-directed constructive learning process. To achieve effective learning outcomes, teaching science and instructional design models are used to guide the development of instructional design strategies that lead to appropriate cognitive processes.

\section{Research Method}

The research method used in the development of learning innovation uses Research Development $(\mathrm{R} \& \mathrm{D})$. The development research method is a method that aims to produce a superior product that is preceded by preliminary research before the product is developed. The goal of $R \& D$ in education is not to formulate or test theories but to develop effective products for use in schools.

\subsection{Research Model According to Borg \& Gall}

The educational research and development model according to Borg \& Gall (2003) in the book "Educational Research", explains that development research in education is an industry-based development model where the findings of the research are used to design learning products which are then systematically tested in the field, evaluated and perfected until a learning product is produced that meets certain standards, namely: effective, efficient, and of high quality.

The R\&D stages by referring to Borg \& Gall (1983) include 10 steps, namely: 1. Research and Information Collection (conducting research and gathering information), 2. 
Planning (making plans), 3. Developing Preliminary Forms of Product (developing forms initial product, 4. Preliminary Field Testing (conducting initial field tests), 5. Main Product Revision (conducting major product revisions, 6. Main Field Testing (conducting field tests for main products), 7. Operational Product Revision (conducting operational product revisions ), 8. Operational Product Testing (conducting field tests on products), 9. Final Product Revision (making final product revisions), 10. Dissemination and Implementation (dissemination and implementation).

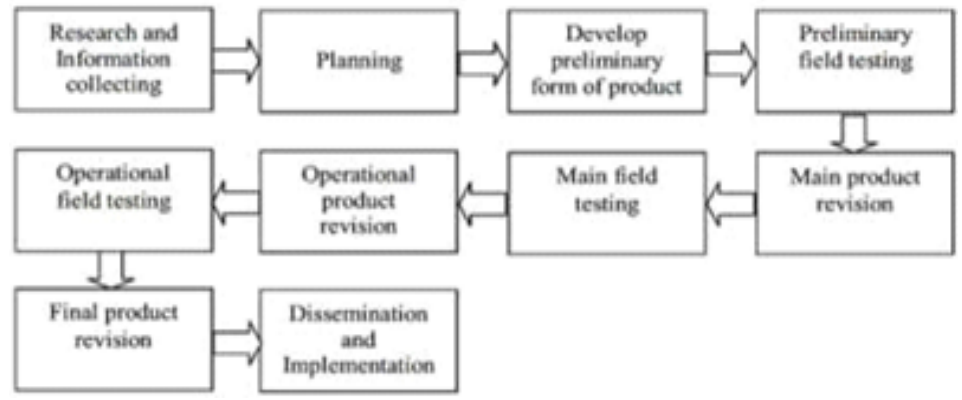

Figure 3. The Stages of the R\&D Model According to Borg \& Gall

\subsection{Dick \& Carey System Approach Model}

The R\&D model developed by Dick \& Carey is a systems approach model or a procedural approach model, namely a research model that suggests that the application of development design principles be adjusted according to the steps that must be taken sequentially. The steps of the Dick \& Carey research and development model are characteristic of the R\&D method in general, which are grouped into 5 research and development procedures, namely: analysis, development, design, implementation, and evaluation. The five steps of the procedure are interpreted in the 10 steps of the Dick \& Carey development model, namely: 1) Analysis, contains three procedural steps in the Dick \& Carey development model: needs assessment to identify the goal (s), conduct instructional analysis, and analysis of learners \& contexts. 2) Development (develop), 3) Design (design), and 4) Implementation (implement) is three procedural steps in the form of a cycle that is carried out until the expected development model is found, then in stage 5 ,) Evaluation is taken through formative evaluation and summative evaluation.

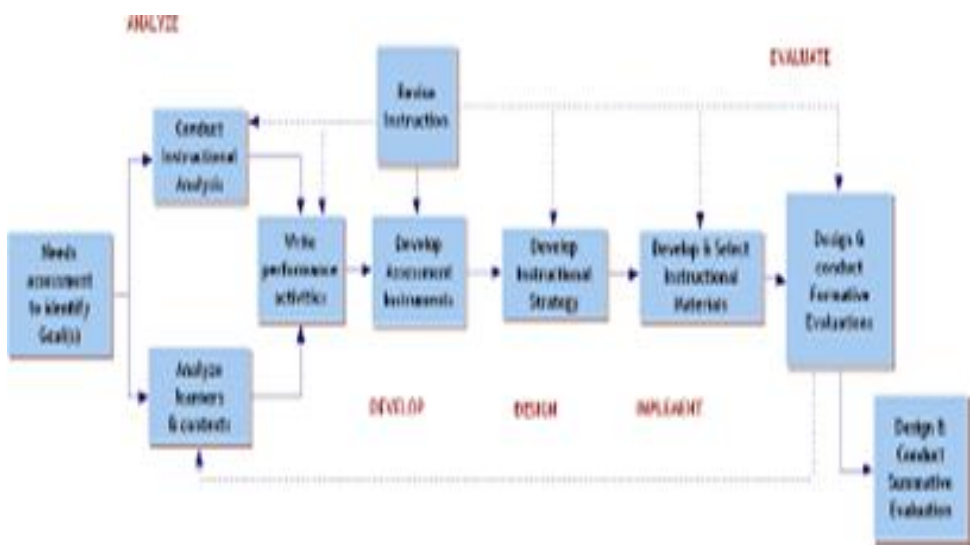

Figure 4. The Dick \& Carey System Approach Model 


\subsection{Development Procedures}

The development model used in developing learning media in this study is the Borg and Gall (1983) development model combined with the Dick and Carey (2005) learning development model which has developmental steps to produce instructional media products divided into 5 stages, namely: doing preliminary research, making software designs developed in learning media, collecting materials begins with data collection, making and collecting animated images, recording and collecting audio, creating and producing multimedia-based interactive learning media equipped with media instructions, and reviewing and testing product trials or field trials in the context of product revision and formative evaluation.

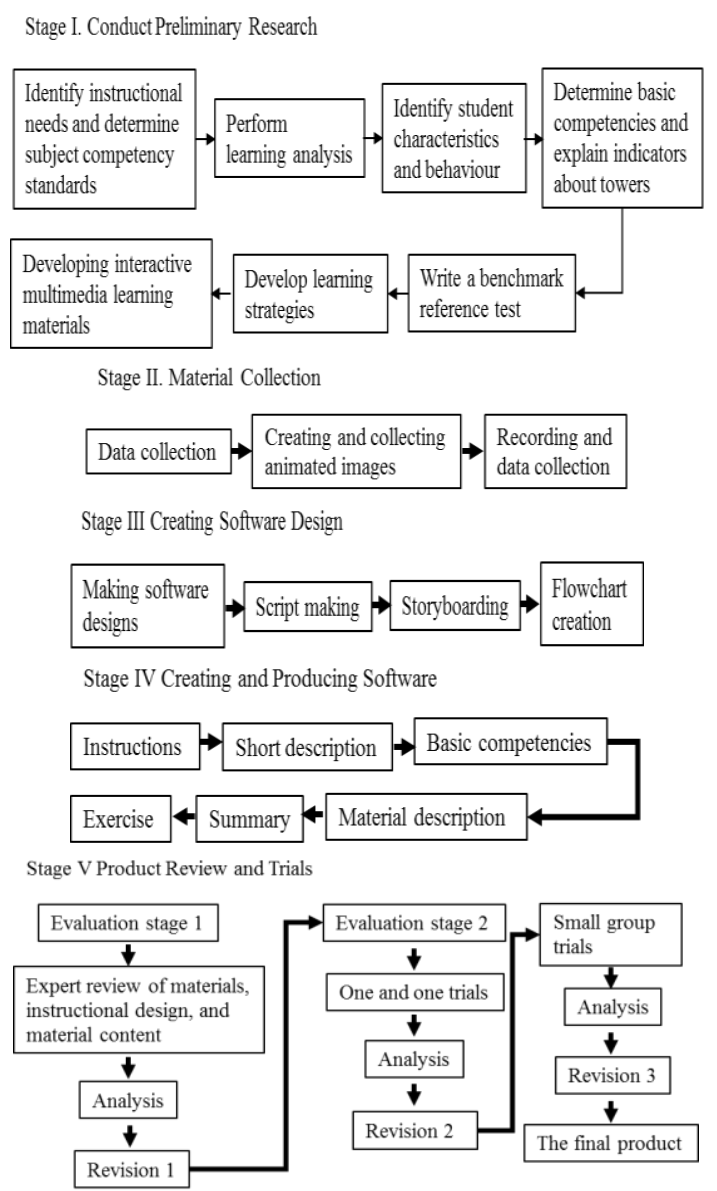

Figure 5. Interactive Multimedia Development Procedure

\section{Discussion}

The results showed: (1) the validation of the learning design expert as a whole showed an average score of 3.97 in the feasible category, (2) the validation of the content / material experts as a whole showed an average score of 4.32 in the very feasible category, (3) the validation The software engineering construction experts as a whole showed an average value of 4.38 very feasible categories, (4) individual trials as a whole showed an average value of 3.97 in the feasible category, (5) small group trials as a whole showed an average of 3.56 decent categories. The results of product validation for the development of a CBI-based learning model in the subject of electric power transmission networks in 
students of SMK Negeri 1 Percut Sei Tuan, Department of Electrical Power Network Engineering, Electrical Engineering Expertise Study Program, shows the results of the feasibility to be developed.

\subsection{Feasibility of the Developed CBI-Based Learning Model}

The cognitive theory of multimedia learning tends to focus on learning that aims at reducing extraneous processes (highlighting important material) or managing essential processes (breaking lessons down into parts). Multimedia learning cognitive theory follows cognitive load theory differentiating between three types of processing demands on the learner's cognitive system during learning: (a) extraneous processes, which are cognitive processes that do not serve the purpose of teaching and are caused by poor learning design, (b) essential processing, which are cognitive processes that aim to represent the material presented mentally and are caused by the complexity of the material, and (c) Generative processing, which is a cognitive process that aims to understand material and is caused by the efforts of learners to be involved in the learning process such as selecting, organizing, and integrating.

Based on the cognitive theory of multimedia learning, research on instructional design principles initially focused on techniques for minimizing extraneous processing (reducing extraneous words and graphics or highlighting key material), and gradually expanded to include essential processing management techniques (breaking lessons complex into manageable parts or provide pre-training in key concepts).

Computer-based instructional simulation is one of the most powerful methods of educational delivery because computer-based instructional simulation provides authentic and situated forms of practice, feedback about performance, a depiction of how a device or system works and motivation to learn while avoiding physical hazards and constraints. The effectiveness of a systematic approach in instructional design provides an empirical and replicable process for reliable assessment to continuously and empirically enhance the learning experience developed. In computer-based learning simulations, students learn by actually carrying out the activities to be studied in a context similar to the real world.

\subsection{The Effectiveness of the Developed CBI-Based Learning Model}

The information processing model is a prevailing theory in cognitive psychology. This includes three types of memory (sensory register, working memory, and long-term memory) that interact to encode the incoming information. The main idea in this theory is that cognitive capacity in working memory is limited so that if the learning task requires too much capacity, learning is hampered. The general principles employing cognitive load theory are to reduce extraneous cognitive load, manage intrinsic cognitive load, and promote germane charge. All information felt by the sensory register will be transferred to working memory when students pay attention to learning. Students use 2 (two) training models when processing information on working memory, namely: (a) Maintenance exercises (memorization) when students read learning material many times to remember, (b) Elaborative exercises (the process of organizing information) to achieve meaning.

Limitations in duration and capacity of working memory are considered important factors when designing instructions. A series of studies have found that individual working memory performance correlates with cognitive abilities and academic achievement. This theory explains the learning process in terms of information processing systems that involve long-term memory to effectively store all human knowledge and skills. Cognitive load theory has been applied with some success in the field of computer learning. 


\subsection{Advice}

Based on the findings that have been described in the conclusions and implications of the research results, the following suggestions are made:

1. Electrical engineering subjects for XI grade students of the Electricity Engineering study program for the Electrical Power Network Engineering major with the electrical power network engineering expertise program at SMK Negeri 1 Percut Sei Tuan require creativity, for this, we need adequate facilities such as practical equipment and equipment and resources. -source required.

2. The product of developing CBI-based learning models in electrical engineering subjects for vocational school students to improve the results of the learning process is one of the tools to help convey messages in the learning process, the existence and ability of teachers to use CBI based learning model development products in electrical engineering subjects for students. Vocational high schools to improve the results of the learning process are needed as facilitators so that class XI students of the Electricity Engineering study program for the Electrical Power Network Engineering major with the power grid engineering expertise program of SMK Negeri 1 Percut Sei Tuan can be actively involved in the learning process.

3. For the product development of a CBI-based learning model in electrical engineering subjects for vocational school students to improve the results of the learning process to be more optimal and suitable for further use, things are needed that can support product development consisting of curriculum developer experts, subject matter expert, financial support and infrastructure and time available.

4. because of limited research time and funds so that there are still many uncontrolled influences, it is necessary to carry out further research on a more representative sample.

\section{Conclusion}

As a result of the rapid development of information and communication technology, the use of computers in education is inevitable. The use of computers in teaching and learning has been carried out to find learning models that can enhance learning. The integration of technology into education means using it as a tool to teach subject matter and to promote problem-solving and higher-order thinking skills. There are software supported educational products designed for use in computers and teaching practices. It was found that the use of computers and teaching packages with materials such as videos, slides, CDs, sound and animation in science and technology courses made it possible to have interactive learning.

\section{References}

Arikunto (2010). Prosedur Penelitian. Jakarta, Rineka Cipta.

Arsyad (2015). Media Pembelajaran. PT RajaGrafindo Persada.

Aslimeri dkk (2008). Teknik Transmisi Tenaga Listrik. Direktorat Pembinaan Sekolah Menengah Kejuruan.

Bahar (2016). Pengembangan Media Pembelajaran Interaktif Menggunakan Simulasi Animasi Pada Mata Kuliah Chasis Otomotif. Tesis. Maret 2016.

Brayshaw (2016). Using Motivation Derived From Computer Gaming In The Context Of

Computer Based Instruction. 2016 SAI Computing Conference (SAI), 13-15 July 
2016. Electronic ISBN: 978-1-4673-8460-5, INSPEC Accession Number: 16267830. https://ieeexplore.iee.org/document/7556074

Connolly (2005). Work in Progress - Computer-based Instruction \& Web-based Tutorials: Effectiveness and Applications. 35th ASEE/IEEE Frontiers in Education Conference, 0-7803-9077-6/05/\$20.00 @ 2005 IEEE, October 19 - 22, 2005, Indianapolis, IN. https://www.academia.edu/4338492/Work_in_Progress_-_Computerbased_Instruction_and_Webbased_Tutorials_Effectiveness_and_Applications?auto=download.

Damayanti (2016). Pengaruh Metode Simulasi Terhadap Hasil Belajar Pada Mata Pelajaran Kewirausahaan Kelas Xi Smkn 14 Bandung. Skripsi. http://repository.unpas.ac.id/11493/

Davis (2015). Applying Dale's Cone of Experience to increase learning and retention: A study of student learning in a foundational leadership course. licensee Bloomsbury Qatar Foundation Journals, World Congress on Engineering Education, 2014. https://www.researchgate.net/publication/281505975_Applying_Dale's_Cone_of_Exp erience_to_increase_learning_and_retention_A_study_of_student_learning_in_a_foun dational_leadership_course

Fadhlan (2019). Model Discovery Learning dalam Pembelajaran Matematika. Article, January 2019. https://www.researchgate.net/publication/330411031_MODEL_DISCOVERY_LEAR NING_DALAM_PEMBELAJARAN_MATEMATIKA

Fathurrohman (2015). Model-Model Pembelajaran Inovatif. Ar-ruzz Media.

Gagne (2008). Mastery Learning and Instructional Design. Performance Improvement Quarterly 1(1):7 - 18, October 2008.

https://www.researchgate.net/publication/229765347_Mastery_Learning_and_Instruct ional_Design

Hidayat, D.F., Adisaputera, A., and Pramuniati, I. (2020). Development of HOTS (High Order Thinking Skill) Based News Text Assessment Instrument for 8 th Grade Students in SMP Muhammadiyah 7 Medan. Budapest International Research and Critics in Linguistics and Education (BirLE) Journal Vol 3 (2): 1123-1136.

Huang (2004). Learning Motivation Evaluation For A Computer-Based Instructional Tutorial Using Arcs Model Of Motivational Design. 34th Annual Frontiers in Education, 2004. https://www.researchgate.net/publication/4130749_Learning_motivation_evaluation_f or_a_computerbased_instructional_tutorial_using_ARCS_Model_of_Motivational_Design

Husain (2010). Computer-Based Instructional Simulations in Education: Why and How. November 2010. https $/ / w w w . r e s e a r c h g a t e . n e t / p u b l i c a t i o n / 272505693$ ComputerBased_Instructional_Simulations_in_Education_Why_and_How

Hooper (2003). The Effect Of Persistence And Small Group Interaction During ComputerBased Instruction. Computers in Human Behavior Volume 19, Issue 2, March 2003, Pages 211-220.

Imelda, and Anzelina, D. (2019). Students' Activities in Learning with Problem Based Learning Based Module to Enhance Students' HOTS on the Subject of Straight Line Equations. Budapest International Research and Critics in Linguistics and Education (BirLE) Journal Vol 2 (4): 552-559.

Khalil, M. K., \& Elkhider, I. A (2016). Applying learning theories and instructional design models for effective instruction. Adv Physiol Educ. 2016 Jun;40(2):147-56. https://www.ncbi.nlm.nih.gov/pubmed/27068989 
Khurniawan (2016). Grand Design Pengembangan Teaching Factory dan TechnoPark. Direktorat Jenderal Pendidikan Dasar dan Menengah Kementerian Pendidikan dan Kebudayaan Republik Indonesia. http://repositori.kemdikbud.go.id/5045/1/DjzUYFjnZL1m58GaC5wH0pK4944YS2J WiOi20Mag.pdf

Kinyua (2017). Effect of Computer Based Instruction on Learners' Performance in Art and Design in Public Secondary Schools in Kenya. Tesis, University of Nairobi, 2017. https:/pdfs.semanticscholar.org/8830/2122fca6c71130ad16488a0b2b9284b4a3b5.pdf

Knowlton (2010). Computer-Based Instruction And Generative Strategies: Conceptual Framework \& Illustrative Example. Article in Computers in Human Behavior 26(5):996-1003, September 2010.

https://www.researchgate.net/publication/223624956_Computerbased_instruction_a nd_generative_strategies_Conceptual_framework_illustrative_example

Koç (2005). Implications of Learning Theories for Effective Technology Integration and Pre-service Teacher Training: A Critical Literature Review. TÜRK FEN EĞİTIMI DERGíSİ Y11 2, Sayı 1, Mayıs 2005.

https://pdfs.semanticscholar.org/c4f2/8d302856a4c6b0e4fbba6dd1a8a8d0326790.pdf

Lowe (2004). "A theory of effective computer-based instruction for adults". LSU Doctoral

Dissertations, May 2004. http://digitalcommons.lsu.edu/gradschool_dissertations/1143

Mappalotteng (2011). Pengembangan Model Pembelajaran Berbantuan Komputer Pada Sekolah Menengah Kejuruan. Disertasi. https://eprints.uny.ac.id/42397

Mayer (2014). Incorporating motivation into multimedia learning. Learning and Instruction 29:171-173 • February 2014.

https://www.researchgate.net/publication/259137980_Incorporating_motivation_into_ multimedia_learning

Miller (2005). Using Learning Styles To Evaluate Computer-Based Instruction. Article in Computers in Human Behavior 21(2):287-306, March 2005. https://www.researchgate.net/publication/222817294_Using_learning_styles_to_evalu ate_computer-based_instruction

Morissan (2012). Metode Penelitian Survei. Kencana, Prenada Media Group

Padmanthara (2004). Pembelajaran Berbantuan Komputer (Pbk) Dan Manfaat Sebagai Media Pembelajaran. TEKNO, Vol:1, Februari 2004, ISSN: 1693-8739. http:/journal.um.ac.id/index.php/tekno/article/view/3234

Powell (2003). A Comparison Of Student Outcomes With And Without Teacher Facilitated Computer-Based Instruction. Computers \& Education Volume 40, Issue 2, February 2003, Pages 183-191. https://www.sciencedirect.com/science/article/pii/S0360131502001203

Reisslein (2005). Computer-Based Instruction On Multimedia Networking Fundamentals: Equational Versus Graphical Representation. IEEE Transactions on Education ( Volume: 48 , Issue: 3 , Aug. 2005 ), Electronic ISSN: 1557-9638, INSPEC Accession Number: 8534877. https://ieeexplore.iee.org/document/1495652

https://www.scienced irect.com/science/article/pii/S074756320200033X

Rusman (2017). Model-Model Pembelajaran Mengembangkan Profesionalisme Guru. PT RajaGrafindo Persada.

Sasmita (2017). Pengembangan Multimedia Interaktif Pembelajaran Pembentukan Alis Mata Dengan Model Pemrosesan Informasi Pada Mata Kuliah Tata Rias Wajah Khusus. Tesis. Januari 2017.

Serin (2011). The Effects Of The Computer-Based Instruction On The Achievement And Problem Solving Skills Of The Science And Technology Students. Turkish Online 
Journal of Educational Technology 10(1), January 2011.

https:/www.researchgate.net/publication/228352956_The_Effects_Of_The_Computer Based_Instruction_On_The_Achievement_And_Problem_Solving_Skills_Of_The_Sci ence_And_Technology_Students

Sweller (1990). Cognitive load as a factor in the structuring of technical material. Journal of Experimental Psychology: General, Vol 119(2), Jun 1990, 176-192. https://psycnet.apa.org/record/1990-26863-001

Tyagita (2015). Edupreneur Dalam Meningkatkan Mutu Lulusan Smk. Prosiding Seminar Nasional Pendidikan Ekonomi \& Bisnis Fakultas Keguruan dan Ilmu Pendidikan Universitas Sebelas Maret: At Surakarta. https://www.researchgate.net/publication/303754108_Edupreneur_Dalam_Meningkat kan_Mutu_Lulusan_SMK

Weise (2000). Technological Enhacement and Design Changes: The Process of Migrating Computer-Based Instruction of an 8th Century Poem to a 21st Century Environment. Conference: Proceedings of IEEE Professional Communication Society International Professional Communication Conference and Proceedings of the 18th Annual ACM International Conference on Computer Documentation: Technology \& Teamwork, Cambridge, Massachusetts, USA, September 24-27, 2000.

https://www.researchgate.net/publication/220961879_Technological_enhancement_an d_design_changes_the_process_of_migrating_computer-

based_instruction_of_an_8th_Century_poem_to_a_21st_Century_environment

Weiss (2002). Principles For Using Animation In Computer-Based Instruction: Theoretical Heuristics For Effective Design. Computers in Human Behavior Volume 18, Issue 4, July 2002, Pages 465-477.

https://www.sciencedirect.com/science/article/pii/S0747563201000498

Williams (2011). Improving Efficirncy In Engineering Education Through Asynchronous Computer-Based Instruction. Conference: Frontiers in Education Conference (FIE), October 2011.

https://www.researchgate.net/publication/261206834_Improving_efficiency_in_engin eering_education_through_asynchronous_computer-based_instruction

Yuberti (2018). Penelitian dan Pengembangan Yang Belum Diminati dan Perspektifnya. Multipath0121.pdf, Uploaded by anon_722913715 on Jul 08, 2018. https://www.scribd.com/document/383425791/Multipath0121-pdf. 